\title{
Intra-urban residential differentiation in the post-Soviet city: the case of Riga, Latvia
}

\author{
ZAIGA KRIŠJĀNE ${ }^{1}$ and MĀRIs BĒRZIN̦Š²
}

\begin{abstract}
Cities in many Central and Eastern European (CEE) countries have transformed rapidly since the political and socio-economic restructuring started in the early 1990s. Economic reforms, growing income inequalities, changes in housing system and selective residential mobility are resulting in increasing socio-spatial differentiation among urban neighbourhoods also in Riga. In addition, little is known about the ethnic dimension of intra-urban residential differentiation, despite the existence of sizeable minority populations. The focus on ethnicity is important, since Riga is the only capital city in the Baltic States where the ethnic majority is outnumbered by the non-Latvian minority. This paper provides empirical evidence about socio-spatial differentiation in Riga according to its ecological structure. Our aim is to examine the characteristics of the inhabitants by distinctive types of urban neighbourhoods with particular interest on ethnicity. The analysis is based on a recent sample survey that was carried out in 2012 and 2013. The results reveal that characteristics of population subgroups differ among urban zones with regard to ethnic origin, age, household size and income. Less pronounced are differences by education, migration background and family type. The conclusion is that Riga is a relatively mixed city at the beginning of the $21^{\text {st }}$ century.
\end{abstract}

Keywords: residential differentiation, segregation, ethnicity, post-Soviet city, Riga, Latvia

\section{Introduction}

Riga's intra-urban spatial structure and socio-economic pattern has been affected by various global and local processes over the past twenty-five years. In academic debate social polarisation caused by these processes (e.g. economic restructuring, globalisation, deindustrialisation, EU enlargement etc.) has

\footnotetext{
${ }^{1}$ University of Latvia, Department of Human Geography, Raina blvd. 19, Riga, LV 1586, Latvia. E-mail: zaiga.krisjane@lu.lv

${ }^{2}$ University of Tartu, Centre for Migration and Urban Studies, Vanemuise 46, Tartu 51014, Estonia. E-mail: maris.berzins@ut.ee
} 
been reflected in growing residential differentiation in CEE cities (ENYEDI, GY. 1998; Kovács, Z. 1999; Ruoppila, S. and KäHriK, A. 2003). Numerous studies on urban change in the formerly centrally planned countries have already focused on socio-spatial differences at intra-urban scale. The most visible signs of growing socio-spatial differentiation have been documented in city centres and suburban zones (BRADE, I. et al. 2009). More recently particular attention has been devoted also to the socialist pre-fab housing estates revealing that these neighbourhoods have largely retained a relatively good image and social mix (Kährik, A. and TAmmaru, T. 2010; MarcińczaK, S. and Sagan, I. 2011; Wiest, K. 2011; Kovács, Z. and Herfert, G. 2012).

Economic restructuring, growing income inequalities, changes in the housing system and selective residential mobility are also resulting in increasing socio-spatial differentiation among urban neighbourhoods in Riga. Therefore, the main aim of this paper is to examine the characteristics of urban residents by distinctive types of urban neighbourhoods with particular interest on ethnicity.

In the former Soviet Union, ethnicity was an additional element of socio-spatial differentiation. The related processes of immigration and industrialisation, and the central allocation of housing led to high levels of ethnic residential segregation (Gentile, M. and SjöBerG, Ö. 2010; Gentile, M. and TAmmaru, T. 2006). It is also widely accepted that ethnic segregation tends to be associated with general socio-spatial differentiation (MUSTERD, S. and Ostendorf, W. 1998) and this undermines social cohesion in cities. However, ethnic segregation was a modestly studied aspect of residential differentiation in post-socialist countries (SмiтH, D.M. 1996).

The current paper focuses on these topics and provides empirical evidence about socio-spatial differentiation in Riga, the capital city of Latvia. The study includes an analysis of the distribution of socio-economic and ethnic groups across three distinctive types of neighbourhoods. The paper is structured as follows. The next section outlines the general processes that reshape the socio-spatial structure of the post-socialist cities. Then, a concise description of Riga is provided with special emphasis on the evolution of the city's residential structure, housing stock and ethnic pattern. Next we proceed by presenting our research data and explaining the applied methods. The contemporary pattern of intra-urban residential differentiation in Riga is more closely examined in the last sections.

\section{Social inequalities and residential differentiation in post-socialist cities}

A wide range of scholarly contributions summarize that socialist cities were less segregated, with rather modest residential differentiation, than it was found in the capitalist cities. This situation was determined by communist poli- 
cies on income and housing distribution (SZELÉNYI, I. 1983; FRENCH, R.A. and Hamilton, F.I. 1979; Sмiтh, D.M. 1996). The return to democracy and market economy initiated multiple processes that rapidly changed existing urban structures. Among the most essential processes that have heavily influenced urban change are - globalisation, deindustrialisation, economic restructuring, labour market segmentation, and welfare state retrenchment (ANDRUsz, G. et al. 1996; Hamilton, F.E.I. et al. 2005; SýKora, L. and Bouzarovski, S. 2012). All these forces and processes have substantially contributed to the changes in the morphological and socio-spatial structure of post-socialist cities (SAILER-FLIEGE, U. 1999; Borén, T. and Gentile, M. 2007; Stanilov, K. 2007).

Social disparities, polarisation and residential segregation became distinguishing characteristics of the post-socialist urban transformation. It is widely acknowledged that the socio-economic transformations have been much more advanced in capital cities (SMith, A. and Timár, J. 2010; MARCińcZAK, S. et al. 2012). Important dimension of residential differentiation in the post-socialist cities is housing. The former domination of state ownership was replaced by private and municipal ownership. Changes in the housing system, privatisation and property restitution triggered social and ethnic residential segregation (Tsenkova, S. and Nedoviċ-Budiċ, Z. 2006; SýKora, L. 2009).

More recent changes in the housing system are affected by the laissez faire neoliberal attitude of local state and substantial involvement of private developers that generate new social inequalities (Hirt, S. et al. 2013; Kovács, Z. and Hegedús, G. 2014). The growing intensity of post-socialist residential differentiation in urban settings are observed through underlying processes that contribute to segregation, suburbanisation, gentrification and socio-economic downgrading of certain neighbourhoods (SÝKORA, L. 2005; KäHRIK, A. and Tammaru, T. 2008; Van Kempen, R. and Murie, A. 2009; Brade, I. et al. 2009; Temelová, J. et al. 2011; Kovács, Z. et al. 2013; MarcińCZAK, S. et al. 2013).

The most popular subjects of empirical investigations in post-socialist cities are inner cities, large housing estates and suburbs on the periphery of large cities. Building on the literature that indicates that residential differentiation is a multifaceted process, this paper questions how the demographic and socio-economic characteristics of population affect residential divisions at the intra-urban scale by focusing on differences among three distinctive urban zones of Riga. Finally, it is also necessary to emphasise that residential restructuring and differentiation is sensitive to historical context and spatial scale.

\section{Riga: urban development and spatial framework of the analysis}

Riga is the capital and largest city of Latvia. At the beginning of 2013 Riga with its 643.6 thousand residents is home to around $32 \%$ of Latvia's two million popula- 
tions (Central Statistical Bureau of Latvia, 2013). Riga enjoys significant primacy within the urban system of Latvia and provides home to almost half (47\%) of the country's urban population. The city as important administrative, trade and cultural centre has maintained its position over centuries. Riga is one of the oldest European capitals, founded at the beginning of the $13^{\text {th }}$ century. Although the city has over 800 years history it started to develop more rapidly in the late $19^{\text {th }}$ century and experienced fast industrial growth when it became one of the main port cities of the Russian Empire (TsenKova, S. 2005; BerG, W. 2011).

At the beginning of the $20^{\text {th }}$ century Riga was the second largest city in the western part of the Russian Empire after St. Petersburg and its population numbered about half a million. However, the most significant impact on Riga's urban structure was made by the socialist period after World War II. Soviet policies of industrialisation and urbanisation were reinforced by immigration of predominantly Russian-speaking population from other parts of the Soviet Union (Tsenkova, S. 2005; Aberg, M. 2005). During the Soviet regime large industrial facilities were established, particularly in the 1960s and 1970s. The population significantly increased, reaching almost one million in 1989.

Since independence, political and economic restructuring took place and Riga started to lose population due to negative demographic growth rates and out-migration. Today, similarly to other large cities in CEE, Riga witnesses a process of steady population decline (Turok, I. and Myкhnenko, V. 2007; Kabisch, N. and HaAse, D. 2011). In fact, the population of Riga has declined rather fast over the past two decades (Table 1).

In addition, post-socialist transition has given rise to a substantial change in the redistribution of population within the city. Intra-urban population dynamics in Riga reveals that inner-city neighbourhoods have lost their population

Table 1. Indicators of the demographic, social and economic conditions in Riga

\begin{tabular}{l|c|c}
\hline \multicolumn{1}{c|}{ Indicator } & 2000 & 2011 \\
\hline Population, 1,000 persons & 764.3 & 658.7 \\
\hline Population change, \% & $\begin{array}{c}81.0 \\
(1989=100 \%)\end{array}$ & $\begin{array}{c}84.0 \\
(2000=100 \%)\end{array}$ \\
\hline \multicolumn{2}{c}{ Share of population by urban zones, $\%$} \\
\hline Inner city & 21.6 & 17.1 \\
Soviet-era housing estates & 72.3 & 74.5 \\
Outer area & 6.1 & 8.4 \\
Net migration rate per 1,000 inhabitants & -8.7 & -7.2 \\
Share of ethnic minorities, \% & 59.0 & 53.7 \\
Share of owner-occupied housing, \% & 63.6 & 74.5 \\
Ratio of population living in Soviet-era housing estates, \% &.. & 71.8 \\
Gini index for Latvia & 33.2 & 35.7 \\
Share in country's GDP, \% & 55.4 & 50.2 \\
\hline
\end{tabular}

.. No data. Source: 2000 and 2011 census; Statistical database of the Central Statistical. Bureau of Latvia 
most intensely over the last decades. Similarly the Soviet-era housing estates are also losing population, but with a much lower pace. As a consequence, the population share of the housing estate zone has slightly increased.

The withdrawal of the state from the housing market during the 1990s was conducted with privatisation vouchers, which were given to all individuals who had permanently lived and worked in Latvia. Thus, large numbers of sitting tenants mostly in the Soviet-era pre-fab housing estates became owners. Whereas people who lived in restituted houses could not buy their flats, but instead they became tenants of private rental dwellings. As a result of large-scale privatisation the housing stock of Riga is dominated by the owner occupied sector (Table 1). In Riga approximately $60 \%$ of the housing stock has been built after World War II, during the Soviet period (Tsenkova, S. 2005; Bertaud, A. 2006) and most people still lives in pre-transition housing stock.

Empirical evidence suggests that diversification of urban economies, associated with the transition from centrally planned industrial to serviceoriented economy, has become more prominent in capital cities (Dunford, M. and Smith, A. 2000; StenNing, A. 2004). Riga accounts half of the country's GDP and it has a highly centralised system of governance with dominant role in Latvian economy (PAAlzow, A. et al. 2010). The city has traditionally been the main attraction of investment and employment in the Baltic region and has held primacy over Latvia's economic, political, social and cultural life. With respect to the scale of socio-economic inequalities, the widely used Gini index well reflects the scale of income disparities. The available data reveal that the socio-economic inequalities rose over the past decade.

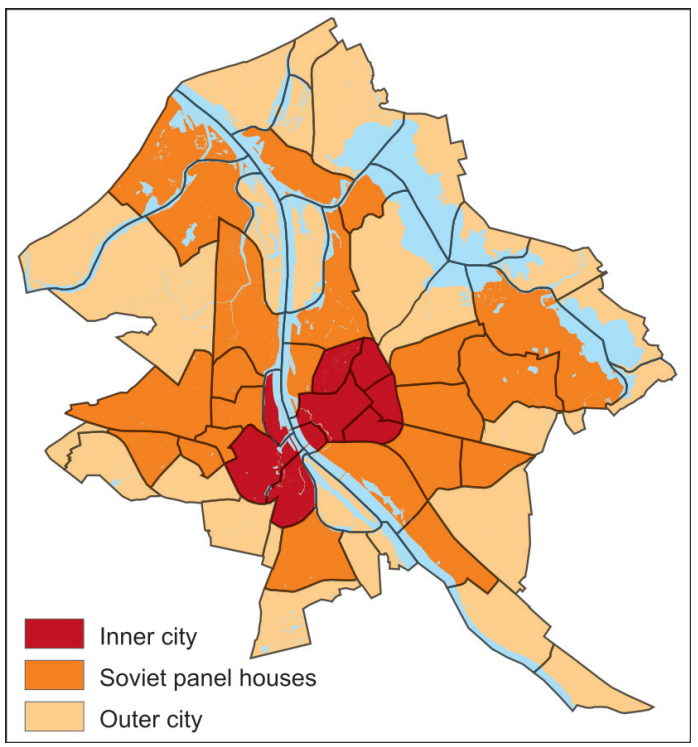

For the sake of our study, based on historical development and following the boundaries of neighbourhoods, the area of Riga was divided into three distinctive urban zones. The inner-city constitutes a more or less compact area in the texture of the city located on both sides of the river Daugava (Figure 1).

Fig. 1. Subdivision of Riga's neighbourhoods by urban zones 
However, the urban landscape of the area has its own set of disparities. The 'Old Town' lies in the very centre of this zone representing the well preserved medieval core and cultural heritage of the Old Hanseatic Town cityscape (Photo 1). The 'Old Town' is surrounded by rows of Art Nouveau buildings and attractive parks on the right bank of the river. Neighbourhoods situated on the left bank and the external part of the inner-city could be characterised as pre-socialist middle- and working-class apartment blocks with adjacent industrial estates that offered good opportunities to work.

The most distinctive type of housing in Riga is the high-rise standardised and pre-fab housing estates found in many neighbourhoods (Photo 2). These residential districts were conceived during the Soviet-era as social units completed with all necessary residential services, being the most significant spatial manifestations of the ideological goals of the communist system (Sмітн, D.M. 1996; Grava, S. 2007). In Latvia the large-scale construction of pre-fab housing estates started in 1959 (RuBīns, J. 2004). The height of the houses, size and quality of the apartments increased in the 1970s and 1980s (Sмiтh, D.M. 1996; TreIjA, S. 2009). In Riga Soviet-type pre-fab housing estates occupy vast areas on both banks of the river. A distinct feature of Soviet cities, compared to those in CEE, is the significant proportion of Russian-speaking immigrant population in the panel housing districts (Gentile, M. and Tammaru, T. 2006; Kährik, A. and Tammaru, T. 2010; Hess, D. et al. 2012).

The outer-city is the most diverse with respect to land use patterns and housing stock. This type generally covers neighbourhoods with single family housing districts (Photo 3) including pre-socialist villas and summer cottages, Soviet-era dacha settlements and extensive territories of allotment gardens. There are also large lakes, wetlands, and marshes, as well as nature reservations along the sea coast. In all urban zones industrial areas are present to a greater or lesser extent.

Riga has been a multi-ethnic and trans-cultural city from its very inception that makes it so vibrant, rich and attractive (BERG, W. 2011). Today, ethnic minorities form 54\% of the total population in Riga and 75\% (264.8 thousand) of the minority population are Russians (Census, 2011). Other large ethnic groups are Byelorussians (7\% of minorities) and Ukrainians (6\%) who mostly speak Russian and, therefore, are named as Russian-speaking minority. As indicated in Figure 2, the spatial differences in the distribution of ethnic groups continue to reflect the pattern inherited from the Soviet past, with Russian-speaking immigrants being over-represented in Soviet-type pre-fab housing estates. Similar situation is found in other countries across the former Soviet Union (Gentile, M. and Tammaru, T. 2006; Kährik, A. and Tammaru, T. 2010). The return of Soviet-era immigrants to their home countries resulted in an increase in the overall proportion of Latvians in Riga, from 41\% in 2000 to $46 \%$ in 2011 (Figure 2). 


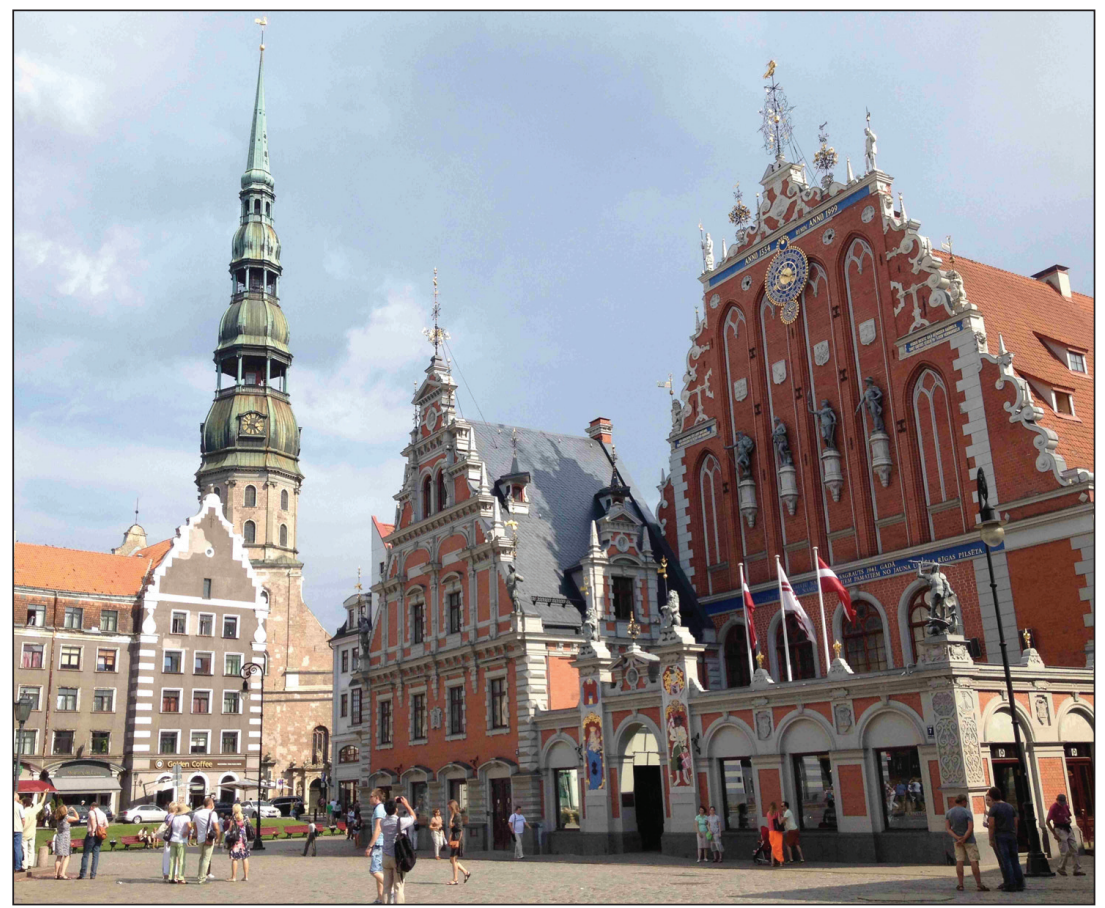

Photo 1. Inner-city, the Town Hall Square of Riga. Source: authors' photograph

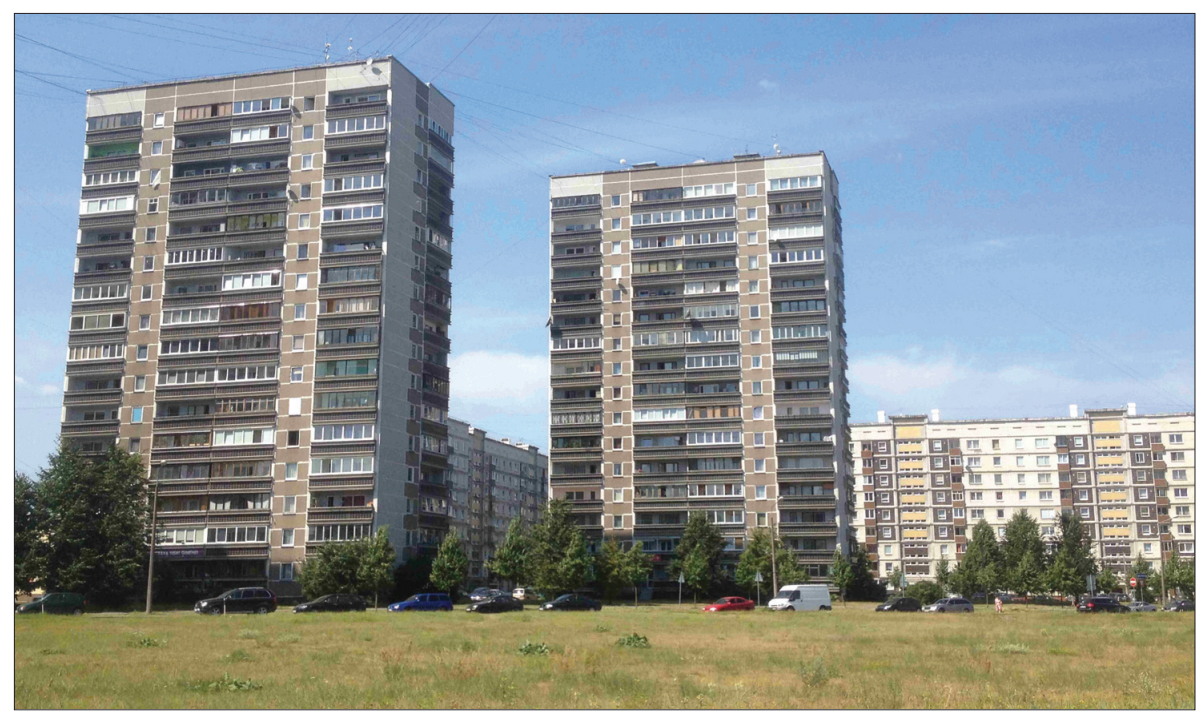

Photo 2. Pre-fab housing estate built in the 1970s. Source: authors' photograph 


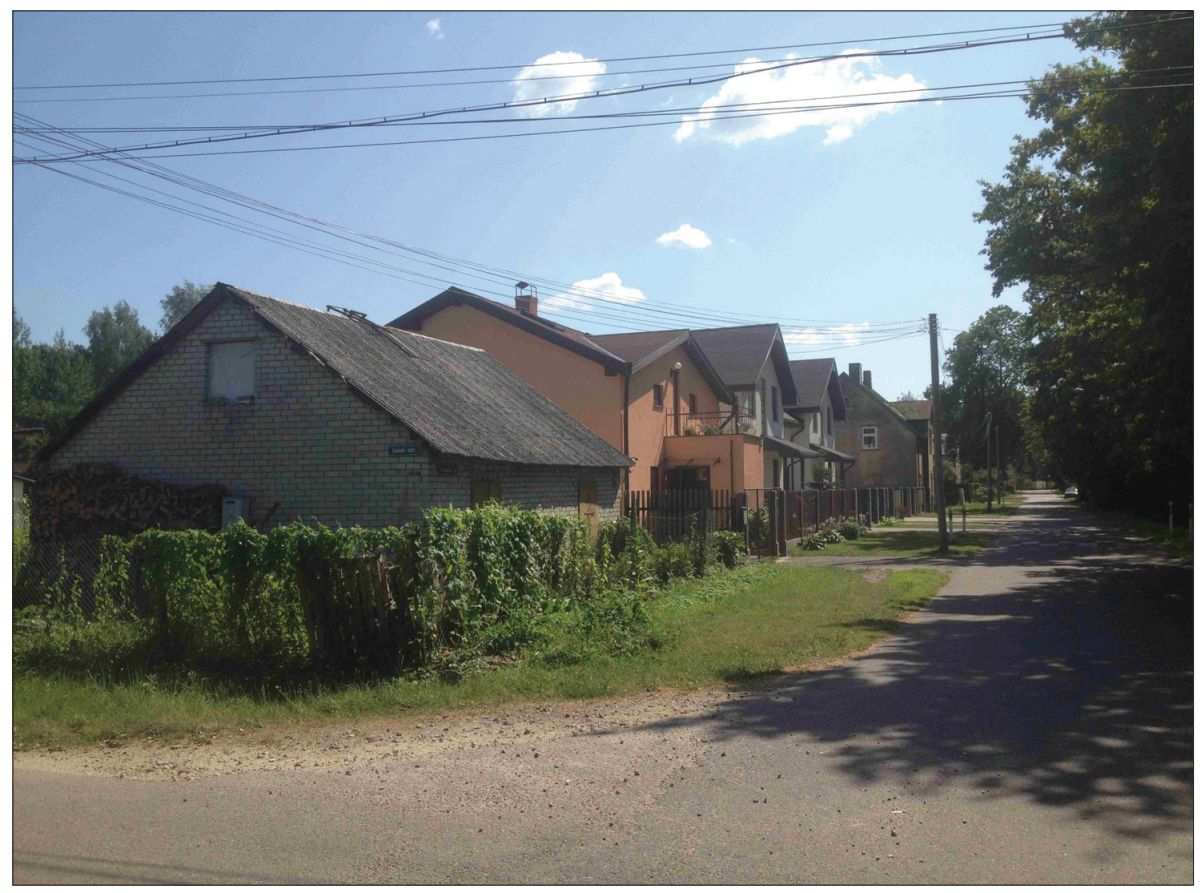

Photo 3. Detached housing in the outer part of the city. Source: authors' photograph

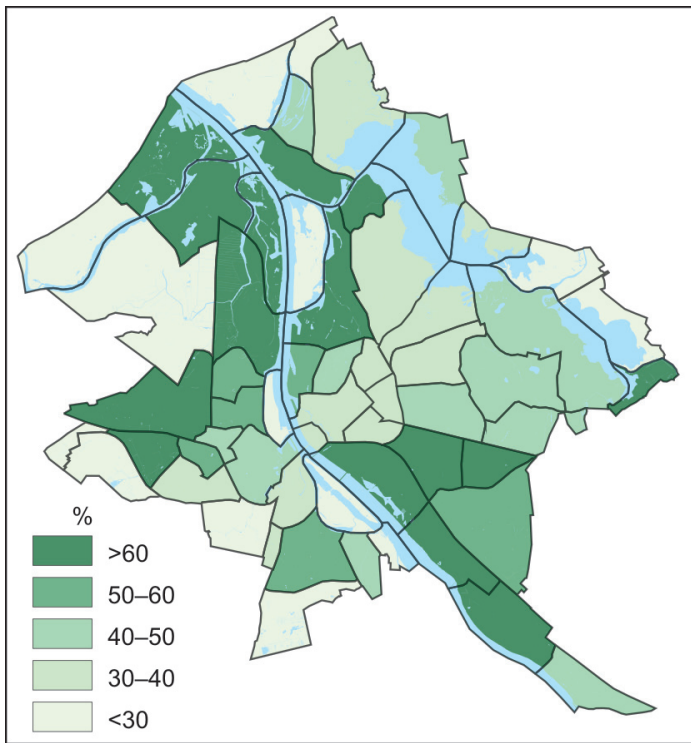

Fig. 2. Share of ethnic minorities in Riga, in \% 


\section{Research data and methods}

For the analysis of intra-urban residential differentiation, we use data from a survey that was carried out among inhabitants of Riga in 2012 and 2013 in collaboration with the municipality. The survey was aimed at understanding the composition of population, residential satisfaction and various aspects of urban life. For this purpose, it contained a number of questions on individual and household characteristics which are of particular use for this paper. The survey is based on a random sample of residents aged 18-78 who were contacted on their own premises for a face-to-face interview. Initially, during the survey, interviewers visited around 5,000 addresses. The sample comprised 3,131 respondents whose age was in the acceptable range and who did not refuse to answer. The response rate was $62.6 \%$. Among the individuals included in the sample $17.2 \%$ live in the inner-city, $55.5 \%$ are residents of the Soviet-era housing estates, while $27.3 \%$ live in the outer-city. As can be seen, the outer-city is slightly over-represented if we compare to the actual distribution of inhabitants within the city.

The variables we used in the comparative analysis of Riga's urban zones were selected according to two general criteria. They had to refer either to the demographic or the socio-economic status of the residents. Thus, our analysis focuses on the main demographic (gender, age, ethnicity) and family related variables (family status, household type and size). The socio-economic status is identified through educational attainment, income and to a lesser extent employment sector. We have also used a variable referring to migration background. Unfortunately, our data do not include housing characteristics that would have been very useful. However, the main strength of using the survey data, from the perspective of the current analysis, is that it enables the joint study of different population groups based on the place of residence. Due to the relatively small size of the sample, the study was restricted to using crude spatial categories within the framework of urban neighbourhoods.

Our data reveal certain differences between the inhabitants of the inner-city and the other two zones when the population is split by age, education, income and employment sector (Table 2).

The share of young and higher-status people (education, income, employment) is higher in the inner-city when compared with the outer-city and housing estates. The opposite picture was found when comparing the outercity with the other two zones. From the data presented in Table 2, we can see that elderly people with low socio-economic status, as well as single person households tend to live in the outer-city.

In the next stage the same set of variables was applied for the main ethnic groups. There are some important differences between members of the majority and the minority populations in Riga (Table 3). First, as one would 
Table 2. Comparison of research populations in the different urban zones, $\%$

\begin{tabular}{|c|c|c|c|c|c|}
\hline \multicolumn{2}{|c|}{ Indicators } & Total & $\begin{array}{c}\text { Inner- } \\
\text { city }\end{array}$ & $\begin{array}{c}\text { Housing } \\
\text { estates }\end{array}$ & $\begin{array}{l}\text { Outer- } \\
\text { city }\end{array}$ \\
\hline \multirow{3}{*}{ Ethnic origin } & Latvian & 41.9 & 55.8 & 36.6 & 44.0 \\
\hline & Russian & 50.0 & 39.2 & 54.1 & 48.5 \\
\hline & other & 8.1 & 5.0 & 9.3 & 7.5 \\
\hline \multirow{2}{*}{ Gender } & male & 43.1 & 43.7 & 42.6 & 43.9 \\
\hline & female & 56.9 & 56.3 & 57.4 & 56.1 \\
\hline \multirow{6}{*}{ Age group } & under 24 & 12.7 & 15.9 & 13.2 & 9.8 \\
\hline & $25-34$ & 18.6 & 20.6 & 19.3 & 15.8 \\
\hline & $35-44$ & 15.3 & 15.4 & 15.7 & 14.2 \\
\hline & $45-54$ & 17.7 & 17.5 & 18.0 & 17.1 \\
\hline & $55-64$ & 15.3 & 12.8 & 16.5 & 14.2 \\
\hline & over 65 & 20.4 & 17.8 & 17.3 & 28.9 \\
\hline \multirow{2}{*}{ Family status } & married, in cohabitation & 52.3 & 52.2 & 52.6 & 51.6 \\
\hline & single & 47.7 & 47.8 & 47.4 & 48.4 \\
\hline \multirow{2}{*}{ Household type } & have children under 18 & 31.2 & 31.8 & 30.8 & 31.6 \\
\hline & have no children under18 & 68.8 & 68.2 & 69.2 & 68.4 \\
\hline \multirow{3}{*}{ Household size } & 1 person & 19.2 & 19.7 & 17.1 & 23.0 \\
\hline & 2 persons & 33.0 & 32.7 & 34.2 & 30.8 \\
\hline & 3 and more persons & 47.8 & 47.6 & 48.6 & 46.2 \\
\hline \multirow{2}{*}{ Place of birth } & Riga (non-migrant) & 19.9 & 21.2 & 20.1 & 18.7 \\
\hline & outside Riga (migrant) & 80.1 & 78.8 & 79.9 & 81.3 \\
\hline \multirow{3}{*}{ Level of education } & primary & 6.7 & 5.4 & 6.9 & 7.2 \\
\hline & secondary & 60.7 & 56.5 & 62.0 & 60.7 \\
\hline & university & 32.6 & 38.1 & 31.1 & 32.1 \\
\hline \multirow{4}{*}{ Income per person } & less than 300 EUR & 36.7 & 31.0 & 39.1 & 35.4 \\
\hline & between 300 and 500 EUR & 25.0 & 21.9 & 25.1 & 26.6 \\
\hline & more than 500 EUR & 8.7 & 11.0 & 7.8 & 9.1 \\
\hline & no answer & 29.6 & 36.1 & 27.9 & 28.9 \\
\hline \multirow{3}{*}{ Employment sector } & public & 19.6 & 21.2 & 19.8 & 18.2 \\
\hline & private & 43.0 & 47.6 & 43.0 & 40.1 \\
\hline & inactive / unemployed & 37.4 & 31.2 & 37.2 & 41.7 \\
\hline \multicolumn{2}{|l|}{ Sample: } & $\mathrm{N}=3,131$ & $\mathrm{~N}=538$ & $\mathrm{~N}=1,738$ & $\mathrm{~N}=857$ \\
\hline
\end{tabular}

expect, the share of non-Latvians is higher in the Soviet-era housing estates, while Latvians are over-represented in the inner-city. Moreover, with respect to ethnic divisions, the share of Latvians has increased in all urban zones, but especially in the inner-city. On the one hand, this is due to the return migration of Russian-speaking people after Latvia regained its independence (HELENIAK, T. 2004; EgLīTe, P. 2009), and in-migration of Latvians from other urban and rural areas on the other (KRIŠJĀNE, Z. and BĒRZIN̦š, M. 2012).

Similarly, the age structure and the socio-economic composition differs by ethnicity - Latvians are younger, better educated and earn a higher- 
Table 3. Selected variable by main ethnic groups, $\%$

\begin{tabular}{|c|c|c|c|c|c|}
\hline \multicolumn{2}{|r|}{ Indicator } & Total & Latvian & Russian & Other \\
\hline \multirow{3}{*}{ Urban zone } & Inner-city & 17.2 & 22.8 & 13.5 & 10.7 \\
\hline & Soviet housing estates & 55.5 & 48.4 & 60.0 & 64.0 \\
\hline & Outer-city / mixed use & 27.3 & 28.7 & 26.5 & 25.3 \\
\hline \multirow{2}{*}{ Gender } & male & 43.1 & 43.1 & 44.0 & 37.9 \\
\hline & female & 56.9 & 56.9 & 56.0 & 62.1 \\
\hline \multirow{6}{*}{ Age group } & under 24 & 12.7 & 13.3 & 13.3 & 5.5 \\
\hline & $25-34$ & 18.6 & 20.6 & 18.3 & 10.3 \\
\hline & $35-44$ & 15.3 & 16.3 & 15.1 & 11.1 \\
\hline & $45-54$ & 17.7 & 17.6 & 17.5 & 18.6 \\
\hline & $55-64$ & 15.3 & 12.6 & 16.5 & 20.9 \\
\hline & over 65 & 20.4 & 19.6 & 19.3 & 33.6 \\
\hline \multirow{2}{*}{ Family status } & married, in cohabitation & 52.3 & 51.1 & 54.1 & 46.6 \\
\hline & single & 47.7 & 48.9 & 45.9 & 53.4 \\
\hline \multirow{2}{*}{$\begin{array}{l}\text { Household } \\
\text { type }\end{array}$} & Have children under 18 & 31.2 & 33.4 & 31.0 & 20.9 \\
\hline & have no children & 68.8 & 66.6 & 69.0 & 79.1 \\
\hline \multirow{3}{*}{$\begin{array}{l}\text { Household } \\
\text { size }\end{array}$} & 1 person & 19.2 & 20.0 & 17.6 & 24.5 \\
\hline & 2 persons & 33.0 & 31.2 & 33.8 & 38.3 \\
\hline & 3 and more persons & 47.8 & 48.8 & 48.6 & 37.2 \\
\hline \multirow{2}{*}{ Place of birth } & Riga (non-migrant) & 19.9 & 19.5 & 21.7 & 11.1 \\
\hline & outside Riga (migrant) & 80.1 & 80.5 & 78.3 & 88.9 \\
\hline \multirow{3}{*}{$\begin{array}{l}\text { Level of } \\
\text { Education }\end{array}$} & primary & 6.7 & 6.6 & 6.6 & 8.3 \\
\hline & secondary & 60.7 & 57.0 & 63.9 & 59.7 \\
\hline & university & 32.6 & 36.4 & 29.5 & 32.0 \\
\hline \multirow{4}{*}{$\begin{array}{l}\text { Income per } \\
\text { person }\end{array}$} & less than 300 EUR & 36.7 & 34.3 & 36.9 & 47.4 \\
\hline & between 300 and 500 EUR & 25.0 & 27.3 & 24.4 & 16.6 \\
\hline & more than 500 EUR & 8.7 & 11.3 & 7.3 & 4.0 \\
\hline & no answer & 29.6 & 27.1 & 31.3 & 32.0 \\
\hline \multirow{3}{*}{$\begin{array}{l}\text { Employment } \\
\text { sector }\end{array}$} & public & 19.6 & 23.4 & 16.9 & 16.6 \\
\hline & private & 43.0 & 44.3 & 43.8 & 31.6 \\
\hline & inactive / unemployed & 37.4 & 32.3 & 39.3 & 51.8 \\
\hline \multicolumn{2}{|l|}{ Sample: } & $\mathrm{N}=3,131$ & $\mathrm{~N}=1,313$ & $\mathrm{~N}=1,565$ & $\mathrm{~N}=253$ \\
\hline
\end{tabular}

than-average income per person as compared to non-Latvians. Other demographic, household and employment compositions vary across the analysed ethnic groups as well. Interestingly, the socio-demographic composition of other ethnic minorities, mainly Ukrainians and Byelorussians, is much worse compared to Latvians and Russians. The explanation for this finding relates to pronounced signs of aging as a result of massive wave of ethnic migration after dissolution of the Soviet Union (Mežs, I. 2011; BĒrzinšs, A. and Zvidrin̦š, P. 2012). The results of previous studies are similar to ours, ethnic minorities are more likely to be unemployed or inactive, than Latvians (AAsLAND, A. and FLØtTen, T. 2001). 
We employ binary logistic regression in order to analyse the residential differences between the three urban zones. The regression equation can be formalised as follows:

$$
\log \frac{p\left(Y_{i}=1\right)}{p\left(Y_{i}=0\right)}=\alpha+\sum_{k=1}^{K} \beta_{k} X_{i k},
$$

where is the probability that an individual ,... I lives in the inner-city in models 1 and 2, and in the Soviet-era housing estates in model 3; is the probability that an individual ,... I lives in the outer-city in models 2 and 3, or in the Soviet-era housing estates in model $1 ; \alpha$ is a constant, $X_{i k}$ is the value of variable $k$ for individual $i$; and $\beta_{k}$ is a parameter describing the impact of variable $k$, with $K$ variables.

\section{Intra-urban residential composition and differentiation}

The study on intra-urban residential differentiation focuses on ethnicity and population groups defined by demographic and socio-economic status. With respect to ethnicity, the study distinguishes between Latvians and ethnic minorities. The latter include mainly Russians, Byelorussians and Ukrainians. In all models ethnic origin was included at first in order to confirm or reject the existence of ethnic differences. From the results, we can see that ethnic differences between urban zones are notable. Latvians are more likely to live in the inner-city than ethnic minorities (Table 4, model 1 and 2).

Nevertheless, if we start to examine differences by comparing people living in the inner-city and Soviet-era housing estates (Table 4, model 1) it becomes evident, that there are statistically significant differences in the basic demographic characteristics except for gender, marital status and household type. The results by other variables are as follows. Unexpectedly, younger people are more likely to live in the inner-city (Table 4, model 1 and 2).

Along with the results confirming that two and more people households are less likely living in the central neighbourhoods this reveals that inner-city areas have been affected by population changes linked to the second demographic transition, such as a rapid rise in the propensity to live alone (Buzar, S. et al. 2005). The results of the first model also show that probability of being inner-city resident is greater for long-term urban residents, highly educated and those with high incomes. Inactive and unemployed residents are less likely to live in the centre of the city.

The next model compares people living in the inner-city with people living in the outer-city (Table 4, model 2). This comparison yields many similar results confirming that elderly people and low income and low social status groups are less likely to live in the inner-city neighbourhoods. Comparison 
Table 4. Binary logistic regression models of intra-urban socio-spatial differentiation in Riga

\begin{tabular}{|c|c|c|c|c|c|c|}
\hline \multirow{2}{*}{ Indicator } & \multicolumn{2}{|c|}{ Model 1} & \multicolumn{2}{|c|}{ Model 2} & \multicolumn{2}{|c|}{ Model 3} \\
\hline & B & Sig. & B & Sig. & B & Sig. \\
\hline \multicolumn{7}{|c|}{ Ethnic origin (base: non-Latvian) } \\
\hline Latvian & 0.804 & $* * *$ & 0.427 & $* * *$ & -0.356 & $* * *$ \\
\hline \multicolumn{7}{|c|}{ Gender (base: female) } \\
\hline male & 0.037 & - & 0.120 & - & -0.153 & * \\
\hline \multicolumn{7}{|c|}{ Age group (base: $25-34$ ) } \\
\hline under 24 & 0.338 & & 0.295 & ** & 0.081 & \\
\hline $35-44$ & -0.384 & .7. & 0.443 & $* *$ & 0.168 & * \\
\hline $45-54$ & -0.336 & t. & -0.600 & *** & -0.276 & * \\
\hline $55-74$ & -0.449 & $* * *$ & -0.696 & $* * *$ & -0.262 & $* * *$ \\
\hline over 75 & 0.045 & & -0.984 & $* * *$ & -0.883 & \\
\hline \multicolumn{7}{|c|}{ Family status (base: single) } \\
\hline married, in cohabitation & 0.140 & - & 0.124 & - & 0.060 & - \\
\hline \multicolumn{7}{|c|}{ Household type (base: have children under 18 ) } \\
\hline have no children under 18 & 0.171 & - & -0.274 & * & -0.343 & $* * *$ \\
\hline \multicolumn{7}{|c|}{ Household size (base: 1 person) } \\
\hline 2 persons & -0.391 & ** & 0.445 & ** & 0.343 & $* * *$ \\
\hline 3 and more persons & -0.407 & ** & -0.044 & - & 0.310 & ** \\
\hline \multicolumn{7}{|l|}{ Place of birth (base: migrant) } \\
\hline Riga & 0.364 & $* *$ & -0.182 & * & 0.127 & - \\
\hline \multicolumn{7}{|c|}{ Level of education (base: primary) } \\
\hline secondary & -0.182 & * & 0.114 & * & -0.035 & \\
\hline university & 0.378 & ** & 0.314 & - & -0.023 & - \\
\hline \multicolumn{7}{|c|}{ Incomes (base: less than 300 EUR) } \\
\hline between 300 and 500 EUR & 0.165 & * & 0.391 & $* * *$ & -0.279 & ** \\
\hline more than $500<$ EUR & 0.283 & $* *$ & 0.164 & - & -0.403 & $* *$ \\
\hline no answer & 0.485 & $* * *$ & 0.151 & - & -0.281 & $* * *$ \\
\hline \multicolumn{7}{|c|}{ Employment sector (base: public) } \\
\hline private & 0.067 & - & 0.068 & * & 0.050 & 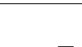 \\
\hline inactive / unemployed & -0.282 & * & -0.310 & - & -0.013 & - \\
\hline
\end{tabular}

Sig. = Significance: ${ }^{*} p<0.10 * * p<0.05^{* * *} p<0.01$

of the inner- and outer-city shows slightly different results with respect to household type and size, and migration background. Unlike to model 1 it becomes apparent that two person households are more likely to live in the inner- than outer-city. Non-migrants are also less likely being residents of central neighbourhoods than those living in the outer zone. Thus, our results partly confirm the impact of residential mobility on growing socio-spatial differences within the city, especially when comparing the inner-city with the other two zones. 
Finally, we compare individual characteristics of residents living in the Soviet-era housing estates with those who are living in the outer-city (Table 4, model 3). Similarly to model 2 we found that outer-city is characterised by higher share of elderly than housing estates. With regards ethnic composition, results show that Latvians are less likely to live in housing estates than ethnic minorities.

Statistically significant differences were found by household type and size as well as by income. Differences in income are very pronounced - residents of the housing estates have lower odds of belonging to the high income groups than residents of the outer zone. There are also important differences between the housing estates and the outer-city according to the household structure. Families without children have the lowest probability of living in Soviet-era housing estates. Finally, two and more person households have a much higher probability of living in an apartment of the housing estates than single person households.

\section{Conclusions}

Since the fall of the Iron Curtain cities in Central and Eastern Europe have rapidly transformed. This urban transformation involved a wide set of social and urban processes generating intense discussion in the literature (BRADE, I. et al. 2009; Gentile, M. et al. 2012; MarcińcZaK, S. et al. 2012; Kovács, Z. and Hegedús, G. 2014). Many scholars assumed that urban changes marked by the reconfiguration of the built environment, changes in the housing system, growing income inequalities, and selective residential mobility is closely followed by increasing residential socio-spatial differentiation (SмIтн, D.M. 1996; EnYedi, Gy. 1998; SÝKora, L. 1999; Ruoppila, S. and Kährik, A. 2003). Indeed, the urban change of Riga has been no exception in terms of rapid development accompanied by these processes. Furthermore, the contextual factors stemming from historical development of the city are important in shaping residential differentiation (Musterd, S. and Kovács, Z. 2013). The contemporary residential structure of Riga is inherited largely from the pre-war period and the Soviet urbanisation.

In this paper we examined the socio-economic characteristics of inhabitants by distinct urban zones with particular interest on ethnicity. Our findings show that residential differentiation has an effect on ethnic concentration in Riga. As it was found Latvians have the highest odds of living in the innercity compared to the housing estates and the outer-city. These results suggest that Latvians are still clearly over-represented in older pre-Soviet apartment houses, while the Russian-speaking people tend to live in dwellings built during the Soviet period. This is consistent with findings of the previous studies 
and reflects the general trend across the former Soviet Union (Kulu, H. and Tammaru, T. 2003; Gentile, M. and Tammaru, T. 2006; Hess, B.D. et al. 2012).

We also found that despite rapidly growing income inequalities and liberalisation of the housing market, the city is still relatively mixed when looking at the socio-economic composition of the different urban zones. Moreover, in spite of of the massive housing privatisation, the residential mobility in Riga is still low and does not generate a significant increase in residential segregation. Nevertheless, most evident signs of population change have been recorded in the inner-city neighbourhoods. Similarly, the most profound differences in terms of population composition are recorded between the inner-city and the other two zones. We interpret these results as follows.

Firstly, the relative attractiveness of older (pre-Soviet) apartments has increased on the housing market, since this housing stock was heavily impacted by the processes of restitution and emigration of ethnic minorities at the beginning of the 1990s. In addition, such dwellings are located in a more attractive residential environment than the standardized Soviet-era housing estates. Secondly, our research revealed that younger people and those with university education and higher incomes have the highest probability of living in the inner-city.

Recently, the evidence of social upgrading was found for several innercity neighbourhoods in different CEE cities (BouzARovsKI, S. 2009; MARCiŃcZAK, S. and SAgan, I. 2011; HaAse, A. et al. 2012; KovÁcs, Z. et al. 2013). This is because the transformation of former socialist cities has brought about the commercialisation, revitalisation and gentrification of urban cores (Temeloví, J. 2007; Kovács, Z. 2009; HaAse, A. et al. 2011). However, the separation of the wealthy social strata remained very limited and selective residential upgrading goes sometimes parallel with deterioration of the pre-war housing stock.

Today the vast majority of the population in Riga lives in the Sovietera housing estates. As expected, the ethnic differences regarding this zone are significant, as many Russian-speaking immigrants, the majority population in the former Soviet Union (FSU), were given priority access to the most modern segments of the housing stock in other republics of the FSU at that time. The main result of the analysis here is that the zone of housing estates in Riga is still characterised by a strong social mix, and do not reveal clear signs of decline in comparison with the inner- and the outer-city. The demographic and socio-economic composition of the people living in the housing estates also changes, but these areas still retain medium to high social status and in comparison with the deteriorated pre-war housing stock of the inner- and the outer-city, they offer better living conditions. Our results are, thus, very similar to findings published for other cities across the region (K̈̈HRIK, A. and Tammaru, T. 2010; Temelová, J. et al. 2011; Wiest, K. 2011; Kovács, Z. and Herfert, G. 2012). 
The outer and peripheral areas of Riga have also experienced certain social change. Initially we expected a rapid increase in socio-economic status also in this urban zone, as suburban-wise development is the most eye-catching process of spatial change in urban periphery in Riga. However, somewhat unexpectedly, our analysis found that predominantly elderly people with low socio-economic status, as well as single person households tend to live in the outer-city. These are surprising results and means that the urban periphery still retains a relatively low socio-economic status in spite of new residential developments. Several outer-city neighbourhoods close to communication infrastructure and within the areas rich in natural amenities have experienced such developments, but it is not reflected by our data.

To conclude, further studies are needed in several fields. Firstly, future research should put more emphasis on the internal differentiation of the outercity neighbourhoods and especially panel housing districts. It is reasonable to expect that the oldest panel estates do experience a more rapid socio-economic downgrading than the newer ones. Secondly, more research should be done on residential mobility in order to better understand the intra-urban movements and the reasons behind them.

Acknowledgement: Authors are grateful for the reviewers for their insightful comments. Special thanks are due to Zoltán Kovács for his kind invitation. This research was supported by the European Social Fund in Mobilitas postdoctoral research grant no. MJD334.

\section{REFERENCES}

Aasland, A. and Fløtten, T. 2001. Ethnicity and social exclusion in Estonia and Latvia. Europe-Asia Studies 53. 1023-1049.

Aberg, M. 2005. Baltic orientations: Globalization, regionalization, or" EU-ization"? In Transformation of cities in Central and Eastern Europe: towards globalization. Eds. Hamilton, F.E.I., Dimitrovska Andrews, K. and Pichler-Milanović, N., Tokyo, United Nations University Press, 399-427.

Andrusz, G., Harloe, M. and Szelényi, I. eds. 1996. Cities after socialism: urban and regional change and conflict in post-socialist societies. Oxford, Blackwell, $340 \mathrm{p}$.

Berg, W. 2011. Riga. In Transcultural Areas. Ed. Berg, W., Wiesbaden, Springer VS Verlag für Sozialwissenschaften, 29-39.

Bertaud, A. 2006. The spatial structures of Central and Eastern European cities. In The urban mosaic of post-socialist Europe. Eds. Tsenkova, S. and Nedović-Budić, Z. Heidelberg, Physica-Verlag, 91-110.

BĒrzin̦š, A. and Zvidrin̦š, P. 2012. Demographic development of Latvians and minorities at the beginning of $21^{\text {st }}$ century. The results of statistical scientific research. Riga, Central Statistical Bureau of Latvia, 5-11. (in Latvian)

Borén, T. and Gentile, M. 2007. Metropolitan processes in post-communist states: an introduction. Geografiska Annaler: Series B, Human Geography 89. (2): 95-110. 
Bouzarovski, S. 2009. Building events in inner-city Gdansk, Poland: Exploring the sociospatial construction of agency in built form. Environment and Planning D) 27. (5): 840-858.

Brade, I., Herfert, G. and Wiest, K. 2009. Recent trends and future prospects of sociospatial differentiation in urban regions of Central and Eastern Europe: A lull before the storm? Cities 26. (5): 233-244.

Buzar, S., Ogden, P.E. and Hall, R. 2005. Households matter: the quiet demography of urban transformation. Progress in Human Geography 29. (4): 413-436.

Central Statistical Bureau of Latvia, 2013. Electronic database. http://www.csb.gov.lv

Dunford, M. and Smith, A. 2000. Catching Up or Falling Behind? Economic Performance and Regional Trajectories in the "New Europe". Economic Geography 76. (2): 169-195.

EgLīte, P. 2009. A Brief Overview of $20^{\text {th }}$ Century Latvian Migration Studies. Folia Geographica XIV. 81-87.

Enyedi, Gr. 1998. Transformation in Central European post-socialist cities. In Social Change and Urban Restructuring in Central Europe. Ed. EnYedi, Gy. Budapest, Akadémiai Kiadó, 9-34.

French, R.A. and Hamilton, F.I. eds. 1979. The socialist city: Spatial structure and urban policy. New York, John Wiley \& Sons, 541 p.

Gentile, M. and SJöвERG, Ö. 2010. Spaces of priority: The geography of soviet housing construction in Daugavpils, Latvia. Annals of the Association of American Geographers 100. (1): 112-136.

Gentile, M. and Tammaru, T. 2006. Ethnicity and housing in the post-Soviet city: Ust'Kamenogorsk, Kazakstan. Urban Studies 43. 1757-1778.

Gentile, M., Tammaru, T. and Van Kempen, R. 2012. Heteropolitanization: social and spatial change in Central and East European Cities. Cities 29. (5): 291-299.

Grava, S. 2007.. Urban transport in the Baltic republics. In The post-socialist city: urban form and space transformations in Central and Eastern Europe after socialism. Ed. STANiLov, K., Dordrecht, Springer, 313-343.

Haase, A., Grossmann, K. and Steinführer, A. 2012. Transitory urbanites: New actors of residential change in Polish and Czech inner cities. Cities 29. (5): 318-326.

Haase, A., Steinführer, A., Kabisch, S., Grossmann, K. and Hall, R. eds. 2011. Residential change and demographic challenge. The inner city of East Central Europe in the $21^{\text {st }}$ century. Burlington, Ashgate Farnham, 376 p.

Hamilton, F.E.I., Dimitrovska Andrews, K. and Pichler-Milanović, N. eds. 2005. Transformation of cities in Central and Eastern Europe: towards globalization. Tokyo, United Nations University Press, 519 p.

Heleniak, T. 2004. Migration of the Russian Diaspora after the Breakup of the Soviet Union. Journal of International Affairs-Columbia University 57. (2): 99-118.

Hess, D., Tammaru, T. and Leetmaa, K. 2012. Ethnic differences in housing in post-Soviet Tartu, Estonia. Cities 29. (5): 327-333.

Hirt, S., Sellar, C. and Young, C. 2013. Neoliberal Doctrine Meets the Eastern Bloc: Resistance, Appropriation and Purification in Post-Socialist Spaces. Europe-Asia Studies 65. (7): 1243-1254.

Kabisch, N. and HAASE, D. 2011. Diversifying European agglomerations: evidence of urban population trends for the 21st century. Population, Space and Place 17. (3): 236-253.

Kährik, A. and TAmmaru, T. 2008. Population composition in new suburban settlements of the Tallinn metropolitan area. Urban Studies 45. (5-6: 1055-1078.

Kёнгік, A. and TаммаRU, T. 2010. Soviet prefabricated panel housing estates: Areas of continued social mix or decline? The case of Tallinn. Housing Studies 25. 201-219. 
Kovács, Z. 1999. Cities from state-socialism to global capitalism: an introduction. GeoJournal 49. 1-6.

Kovács, Z. 2009. Social and Economic Transformation of Historical Neighbourhoods in Budapest. Tijdschrift voor Economische en Sociale Geografie 100. (4): 399-416.

Kovács, Z. and Hegedús, G. 2014. Gated communities as new forms of segregation in postsocialist Budapest. Cities 36. 200-209.

Kovács, Z. and Herfert, G. 2012. Development pathways of large housing estates in postsocialist cities: An international comparison. Housing Studies 27. (3): 324-342.

Kovács, Z., Wiessner, R. and Zischner, R. 2013. Urban renewal in the inner city of Budapest: Gentrification from a post-socialist perspective. Urban Studies 50. (1), 22-38.

KRIšJĀĀe, Z. and BĒrzIN̦š, M. 2012. Post-socialist Urban trends: new Patterns and Motivations for Migration in the Suburban areas of Rīga, Latvia. Urban Studies 49. (2): 289-306.

Kulu, H. and Tammaru, T. 2003. Housing and ethnicity in Soviet Tartu. Yearbook of Population Research in Finland 39. 119-140.

MarcińCZAK, S. and SAGAn, I. 2011. The socio-spatial restructuring of Łódź, Poland. Urban Studies 48. (9): 1789-1809.

MarcińczaK, S., Gentile, M. and StęPniak, M. 2013. Paradoxes of (post) socialist segregation: Metropolitan socio-spatial divisions under socialism and after in Poland. Urban Geography 34. (3): 327-352.

MarcińczaK, S., Musterd, S. and StęPniaK, M. 2012. Where the grass is greener: social segregation in three major Polish cities at the beginning of the $21^{\text {st }}$ century. European Urban and Regional Studies 19. (4): 383-403.

Mežs, I. 2011. Dzimstības etniskie un reǵionālie aspekti Latvijā 1985-2010.gadā (Ethnic and regional aspects of birth rate in Latvia, 1985-2010). Proceedings of the Latvian Academy of Sciences, Section A 65. (3-4): 4-16. (in Latvian)

Musterd, S. and Kovács, Z. eds. 2013. Place-making and Policies for Competitive Cities. Chichester, Wiley Blackwell, 360 p.

Musterd, S. and Ostendorf, W. 1998. Urban segregation and the welfare state: Inequality and exclusion in western cities. London and New York, Routledge, $292 \mathrm{p}$.

Paalzow, A., Sauka, A., Pauna, D., Kilis, R. and Dombrovsky, V. 2010. Policies and strategies in Riga. How to enhance the city's competitiveness No. 10.9. AMIDSt, Amsterdam, University of Amsterdam, $28 \mathrm{p}$.

RuBīns, J. ed. 2004. Rīgas dzīvojamais fonds 20. gadsimtā: Tipologiskā rakursā (Housing stock of Riga in the $20^{\text {th }}$ century: A typological perspective). Rīga, Jumava, 106 p. (in Latvian)

RuoppIlA, S. and Kёнrıк, A. 2003. Socio-economic residential differentiation in post-socialist Tallinn. Journal of Housing and the Built Environment 18. 49-73.

SAILER-Fliege, U. 1999. Characteristics of post-socialist urban transformation in East Central Europe. GeoJournal 49. (1): 7-16.

Sмith, A. and Timár, J. 2010. Uneven transformations: Space, economy and society 20 years after the collapse of state socialism. European Urban and Regional Studies 17. (2): 115-125.

Sмгтн, D.M. 1996. The socialist city. In Cities After Socialism: Urban and Regional Change and Conflict in Post-Socialist Societies. Eds. Andrusz, G., Harloe, M. and Szelényi, I. Oxford, Blackwell, 70-99.

Stanilov, K. ed. 2007. The post-socialist city: urban form and space transformations in Central and Eastern Europe after socialism. Springer, Dordrecht, $495 \mathrm{p}$.

Stenning, A. 2004. Urban change and the localities. In East Central Europe and the former Soviet Union: The post-socialist states. Eds. Bradshaw, M. and Stenning, A., Harlow, Pearson, 87-108. 
SÝKORA, L. 1999. Processes of socio-spatial differentiation in post-communist Prague. Housing Studies 14. (5): 679-701.

SýKorA, L. 2005. Gentrification in post-communist cities. In Gentrification in a global context. Eds. AtKinson, R. and Bridge, G. London, Routledge, 90-105.

SýKORA, L. 2009. New socio-spatial formations: places of residential segregation and separation in Czechia. Tijdschrift voor Economische en Sociale Geografie 100. (4): 417-435.

Sýkora, L. and Bouzarovski, S. 2012. Multiple Transformations Conceptualising the Postcommunist Urban Transition. Urban Studies 49. (1): 43-60.

SzELÉNYI, I. 1983. Urban inequalities under state socialism. New York, Oxford University Press, $158 \mathrm{p}$.

Temelová, J. 2007. Flagship developments and the physical upgrading of the post socialist inner city: The Golden Angel project in Prague. Geografiska Annaler, Series B: Human Geography 89B. (2): 169-182.

Temelová, J., Novák, J., OuŘedniček, M. and Puldová, P. 2011. Housing Estates in the Czech Republic after Socialism Various Trajectories and Inner Differentiation. Urban Studies 48. (9): 1811-1834.

Treija, S. 2009. Housing and social cohesion in Latvia. In Urban Sustainability and Governance: New Challenges in Nordic-Baltic Housing Policies. Eds. Holt-Jensen, A. and Pollock, E. New York, Nova Science Publishers, 197-207.

Tsenkova, S. 2005. Latvia. In Urban issues and urban policies in the new EU countries. Eds. Van Kempen, R., Vermeulen, M., and BaAn, A., Aldershot, Ashgate Publishing, 153-182.

Tsenkova, S. and Nedović-Budic, Z. eds. 2006. The Urban Mosaic of Post-Socialist Europe. Heidelberg, Physica-Verlag, 390 p.

Turok, I. and Mүкнnenko, V. 2007. The trajectories of European cities, 1960-2005. Cities 24. (3): 165-182.

Van Kempen, R. and Murie, A. 2009. The new divided city: changing patterns in European cities. Tijdschrift voor economische en sociale geografie 100. (4): 377-398.

Wiest, K. 2011. Large-Scale Housing Estates in Central and East European Cities: Between Residential Preferences and Local Housing Market Differences. Housing, Theory and Society 28. (4): 410-431. 


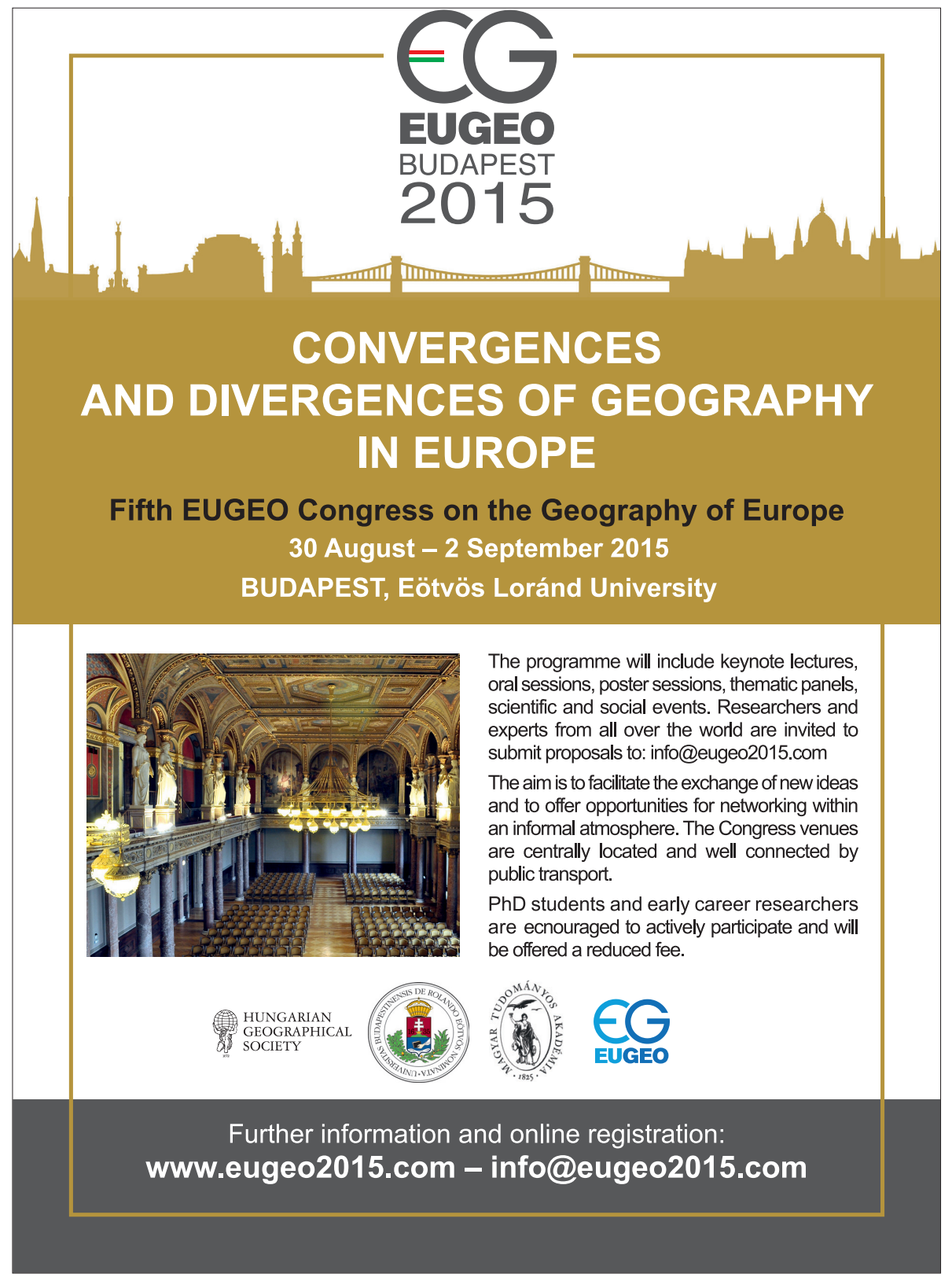

